Creative commons User License: CC BY-NC-ND

Abstracted by: EBSCOhost, Electronic Journals Service (EJS),

Google Scholar, Directory of Open Access Journals (DOAJ),

Journal Seek, Scientific Commons,

Food and Agricultural Organization (FAO), CABI and Scopus
Journal of Agricultural Extension

Vol. 21 (3) October, 2017

ISSN(e): 24086851; ISSN(Print); 1119944X

http://journal.aesonnigeria.org

http://www.ajol.info/index.php/jae

Email: editorinchief@aesonnigeria.org

\title{
Management of Tractor-Hiring Entrepreneurship by Tractor Owners and Hiring Facilities Association of Nigeria
}

https://dx.doi.org/10.4314/jae.v21i3.10

\section{Issa, F. 0.}

Department of Agricultural Extension and Economics,

National Agricultural Extension and Research Liaison Services,

Ahmadu Bello University, Zaria

Email: issafola@gmail.com, Phone:+2348033339312

\section{Abstract}

This study assessed the management of tractor-hiring entrepreneurship by Tractor Owners and Hiring Facilities Association of Nigeria (TOHFAN). Two-stage sampling technique was used to select respondents. A checklist was used in an indepth interview to elicit relevant information which was analyzed qualitatively. Various models of tractor-hiring operations of TOHFAN were identified. The loan guarantee system, the tractor tracking system as well as the business challenges were examined. Data were collected using a checklist in a focus group discussion and key informant interview. Findings revealed that TOHFAN guaranteed loans for its members through collaboration with relevant financial institutions and vendors. Currently (as at December 2016), the association operates with 262 tractors and 757 members across 21 states of the country since 13 years of its establishment. Four distinct models identified were: model involving hiring agent, model involving booking agent, model involving TOHFAN as booking agent, and direct owner-farmer transaction. Tractor tracking device was used to determine the location of each tractor belonging to members. High and unstable interest rate was the major challenge confronting TOHFAN's management of tractorhiring services. This study concludes that TOHFAN's operational model is unique and therefore recommends that investors in tractorhiring services should be encouraged (through creation of awareness by extension agencies) to emulate the TOHFAN example in tractor-hiring management. Models and operational strategies used by TOHAN (especially the tracking device) can be adapted by the public tractor-hiring services in order to ensure effective tractor-hiring management in Nigeria.

Key words: Tractor-hiring, Entrepreneurship, TOHFAN, Nigeria 
Creative commons User License: CC BY-NC-ND

Abstracted by: EBSCOhost, Electronic Journals Service (EJS), Google Scholar, Directory of Open Access Journals (DOAJ), Journal Seek, Scientific Commons,

Food and Agricultural Organization (FAO), CABI and Scopus
Journal of Agricultural Extension

Vol. 21 (3) October, 2017

ISSN(e): 24086851; ISSN(Print); 1119944X

http://journal.aesonnigeria.org

http://www.ajol.info/index.php/iae

Email: editorinchief@aesonnigeria.org

\section{Introduction}

Entrepreneurship is the capacity to develop ideas and achieve success with them. Simply put, it is the task involved in creating an enterprise. Entrepreneurship means taking advantage of opportunities in an environment in order to become self-reliant. Entrepreneurship is the mind-set and process to create and develop economic activities by blending risk-taking, creativity and/or innovation with sound management within a new or an existing organization (Commission of the European Communities, 2003). Udoh (2010) define entrepreneurship as the willingness and ability of an individual or group to seek investment opportunities to establish and run an enterprise successfully by creating something different. Entrepreneurship is the process of identifying, developing and bringing a vision to life regardless of possibilities of success. This could suggest that anyone can be an entrepreneur, or at least has the capacity to develop the vision to create his own enterprise. However, it is clear, that in different situations some individuals will have better options or conditions that they can take advantage to create enterprises or develop innovative products or services through them. Bernier and Hafsi (2003) describe entrepreneurship as a process in which an agent manages to conceptualize and implement an idea, notion, service, product or activity.

An entrepreneur is someone who is able to balance the economically desirable with the technologically/operationally feasible, someone who takes a calculated risk to seize an opportunity or meet unsatisfied needs in hope of establishing a sustainable business. A "tractor-hiring entrepreneur" is an individual or group with the right to use or exploit the tractor and necessary attachments required to carry out agricultural (as well as non-agricultural), forestry or mixed activities. Tractor-hiring is a business involving the hiring out of tractor and implements to farmers for use in exchange for money. The uses include land preparation (such as ploughing, ridging, harrowing), transplanting, planting, fertilizer application, irrigation, application of agrochemicals, harvesting, processing, as well as for non-agricultural purposes such as transportation, electrification and road construction.

Managing tractor-hiring involves the careful application of management principles and business ethics in tractor-hiring business by an individual or group in order to satisfy a predetermined goal. Such goals include the provision and use of machine to boost food production leading to export of the excess in the production thereby generating income for the country through foreign exchange earnings (NICA, 2008; Sims and Kienzle, 2016). The use of tractor ensures greater area under cultivation. According to Mijinyawa and Kisaiku (2006) and Ademade and Jackson (2014), the benefits of tractor use to Nigeria specifically include: timeliness of farming operation, improved yield and increased quality of farm yields. Tractor-hiring is a means of wealth generation for improved livelihood of the entrepreneur as well as other value chain actors in rural areas. This is capable of improving the rural standard of living with positive impacts on other aspect of national life such as employment generation. Efficient management of tractor-hiring will ensure regular availability of tractor for various farm operations and its attendant advantages for farmers. Innovation, the mobilization of resources and the tapping of opportunities are just some of the factors involved in creating a competitive or sustainable enterprise such as tractor hiring. 
Creative commons User License: CC BY-NC-ND

Abstracted by: EBSCOhost, Electronic Journals Service (EJS), Google Scholar, Directory of Open Access Journals (DOAJ), Journal Seek, Scientific Commons,

Food and Agricultural Organization (FAO), CABI and Scopus
Journal of Agricultural Extension

Vol. 21 (3) October, 2017

ISSN(e): 24086851; ISSN(Print); 1119944X

http://journal.aesonnigeria.org

http://www.ajol.info/index.php/iae

Email: editorinchief@aesonnigeria.org

In the recent past, the federal government Nigeria (FGN) approved the implementation of community cooperative tractor-hiring scheme and the payment of $\# 3,153,500,000.00$ as $25 \%$ federal government's equity contribution to the participating companies under the community cooperative Tractor-hiring Scheme (Tractorization Programme) through the public private partnership (PPP) model to make available 1,950 units of various tractors and implements (FGN, 2008). State governments including FCT supported the initiative by providing money for the procurement of tractors and other implements that would be sold to various farmer groups in line with the FGN mechanization policy under private-sector led demand driven community cooperative of the PPP initiative. Various states' tractor-hiring schemes (THS) have invested a lot of resources in procuring tractors and implements to alleviate the problems of mechanization of the small-medium scale farmers and to ensure food security (Alabadan and Yusuf, 2013). Recently, the Federal Ministry of Agriculture and Rural Development (FMARD) facilitated the setting up of Agricultural Equipment Hiring Centers (AEHCs) run by private sector. Eighty (80) AEHCs have taken off with a plan to expand to 774 LGAs (FMARD, 2014; Akeju, 2015).

Tractor Owners and Hiring Facilities Association of Nigeria (TOHFAN) was established in 2003 with 9 tractors and 36 members to provide tractor-hiring services to farmers on a commercial basis. Currently (December, 2016), the association operates in 21 states with 262 tractors and 757 members across the country. TOHFAN is managed by a team of executive members from the head office in Zaria, Kaduna State comprising of chairman, vice-chairman, secretary, assistant secretary, treasurer and public relations officer. At the state level, the association is managed by an executive committee that has similar positions as the head office. A member of TOHFAN can be a tractor owner, tractor mechanic, tractor operator, tractor-hiring agent or a tractor booking agent. TOHFAN as an association does not own a tractor. However, some members have more than one tractor. As an annual obligation, all tractor registered under TOHFAN normally render a day work-service to the Association. Alternatively, a sum of $\$ 20,000$ is paid by each tractor per year as annual due. In addition, a sum of 2,000 is paid on all tractors as monthly due which serve $s$ as another revenue to TOHFAN. Also $1 / 3^{\text {rd }}$ of the revenue accruing from the state chapter is remitted to the national body. A state chapter is granted/inaugurated when and only if there exists no less than 3 tractor owners (and by implication, 3 tractors), 3 operators and at least 1 hiring agent/booking agent/mechanic.

TOHFAN's major activity is provision of tractor-hiring services for small and large scale farmers. In order to ensure efficiency and relevance in the market, it also conducts regular training for all categories of its members as well as providing linkage to financial institutions (for loan), and to farmers (for tractor-hiring). Furthermore, it collaborates with relevant institutions (local and international) and provides management advisory services to ensure business growth.

Previous studies on tractor-hiring focused more on the public service arrangement. However, poor management, leading to high rate of tractor breakdown, and high inefficiency were the bane of public-sector-led tractor hiring services (Rowland, 2004; Dauda et al., 2010). In fact, in a recent appraisal of Anambra state tractor and equipment hiring company (ASTRAC), Umegbalu et al. (2013) identified high 
Creative commons User License: CC BY-NC-ND

Abstracted by: EBSCOhost, Electronic Journals Service (EJS),

Google Scholar, Directory of Open Access Journals (DOAJ),

Journal Seek, Scientific Commons,

Food and Agricultural Organization (FAO), CABI and Scopus
Journal of Agricultural Extension

Vol. 21 (3) October, 2017

ISSN(e): 24086851; ISSN(Print); 1119944X

http://journal.aesonnigeria.org

http://www.ajol.info/index.php/iae

Email: editorinchief@aesonnigeria.org

frequency of tractor breakdown as a major problem of the company (ASTRAC). The study further identified poor maintenance culture, poor funding, and lack of skilled maintenance personnel as reasons for incessant breakdown of machines hence resulting in poor contribution of ASTRAC to agricultural production. Against this background, there arises the need to assess and document the management of private sector led tractor-hiring services of TOHFAN in Nigeria. Sequel to this, policy direction and interventions for improvement can adapt TOHFAN's models for appropriateness and relevance for the attainment of efficient tractorization.

The specific objectives were to:

i. examine the loan guarantee system of TOHFAN;

ii. describe operational models used by TOHFAN;

iii. ascertain the tracking device system employed by TOHFAN; and

iv. identify the challenges confronting TOHFAN.

\section{Methodology}

This survey was conducted in Nigeria between March and June 2016. Various categories of TOHFAN members (tractor owners, operators, mechanics, hiring agents, booking agents) and farmers using tractor-hiring services provided by TOHFAN were interviewed. Tractor owners (members of TOHFAN) across Kaduna, Nasarawa and Niger states and Federal Capital Territory (FCT) were visited to collect relevant information. List of tractor-owners was obtained from TOHFAN Headquarters in Zaria. The four states were purposively selected on the basis of high number of TOHFAN members operating in the states. Ten tractor owners were randomly selected per state and FCT. A checklist was used in an in-depth interview to elicit relevant information from the various categories of interviewees. Data collected was analyzed using qualitative method.

\section{Results and Discussion}

\section{TOHFAN's System of Loan Guarantee}

TOHFAN, as an association, guarantees loan for its members. Players in the loan guarantee system include intending beneficiaries (IB) (who must be members), TOHFAN, banks (FCMB and Sterling), CBN (NIRSAL), and tractor vendors/dealers (TATA: John Deere, SCOA: New Holland, Springfield: Mahindra, and TAK). TOHFAN's major criteria for selection of vendors/dealers are availability of spare parts, and after-sales support. In the arrangement, members are free to select preferred brand and horsepower without being compelled by the association. Figure 1 explains the relationship among players in the loan guarantee system.

TOHFAN partnered with commercial banks for loan assessment for tractor procurement. The partner banks are FCMB and Sterling bank, while Access bank and First bank were also coming on board. Reasons for introducing the loan system included i) difficulties experienced by TOHFAN members in obtaining loans from banks, ii) discouragement of banks to offer loan due to incessant loan default by individuals, iii) the need to facilitate activities of all the value chain actors in 
Creative commons User License: CC BY-NC-ND

Abstracted by: EBSCOhost, Electronic Journals Service (EJS), Google Scholar, Directory of Open Access Journals (DOAJ), Journal Seek, Scientific Commons,

Food and Agricultural Organization (FAO), CABI and Scopus
Journal of Agricultural Extension

Vol. 21 (3) October, 2017

ISSN(e): 24086851; ISSN(Print); 1119944X

http://journal.aesonnigeria.org

http://www.ajol.info/index.php/jae

Email: editorinchief@aesonnigeria.org

TOHFAN, iv) the need to ensure customer satisfaction, and v) the need to remain in business (business mindedness). Repayment scheme (period) for the bank loan is usually 36 months but accelerated repayment is encouraged. Conditions for loan guarantee included: membership requirements, and readiness to comply with rules and regulations (repayment schedule). The Central Bank of Nigeria (CBN) through the Nigeria Incentive-based Risk Sharing System for Agricultural Lending (NIRSAL) de-risks the loan by $75 \%$. In addition, NIRSAL offsets part of the loan interest by paying $40 \%$ to beneficiaries at the completion of repayment of such loan within the stipulated time.

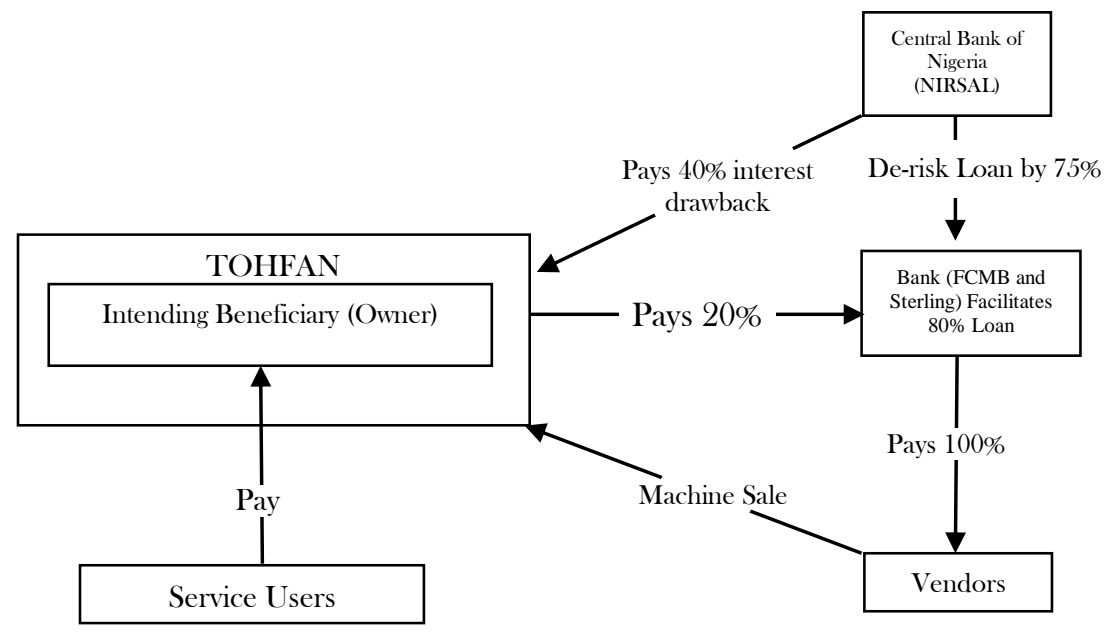

Figure 1: System of loan guarantee by TOHFAN

\section{Models of Tractor-hiring service in TOHFAN}

As a real time business-oriented association, TOHFAN operates in unique ways. Four (4) different models of tractor-hiring services were identified thus:

Hiring agent mode (Model I): In this model (Figure 2), the tractor-hiring agent is the center point. The agent hires machine from the owner for a specified fee and provides services to farmers who pay him. The hiring agent pays the operator and the mechanic as well as fueling the tractor (to the work location only). The hiring agent is a unique partner in the TOHFAN tractor-hiring management. According to TOHFAN operational guidelines, a tractor-hiring agent hires the tractor for at least one week at the rate of about $\$ 20,000$ or more per day as agreed with the tractor owner. He pays directly to the owner. He also pays $\$ 1,000$ to the account of the association before hiring the tractor and $\$ 5,000$ to the association for each transaction made with the tractor owner. He carries out routine servicing of the tractor using original engine oil and filters in conjunction with the tractor operator. He pays $\$ 5,000$ to the operator per day work. He also provides food and accommodates the tractor operator and the assistant operator. Inspection of field where the operator would work and the suitability of the field for tractor operation are 
Creative commons User License: CC BY-NC-ND

Abstracted by: EBSCOhost, Electronic Journals Service (EJS), Google Scholar, Directory of Open Access Journals (DOAJ), Journal Seek, Scientific Commons,

Food and Agricultural Organization (FAO), CABI and Scopus

\author{
Journal of Agricultural Extension \\ Vol. 21 (3) October, 2017 \\ ISSN(e): 24086851; ISSN(Print); 1119944X \\ http://journal.aesonnigeria.org \\ http://www.ajol.info/index.php/jae \\ Email: editorinchief@aesonnigeria.org
}

also done by the hiring agent. The hiring agent is responsible for transporting the tractor to the field of work, fuels the tractor to work, and makes minor repairs that may cost from $\$ 1,000$ to $\$ 5,000$ on the tractor. Essentially, the hiring agent is a business man who hires tractor from the owner, pays the owner, and provides service to farmers for a fee. In this case, the partners function in such a manner that the tractor owners only procure and take care of tractors while the operators can concentrate on machine operation.

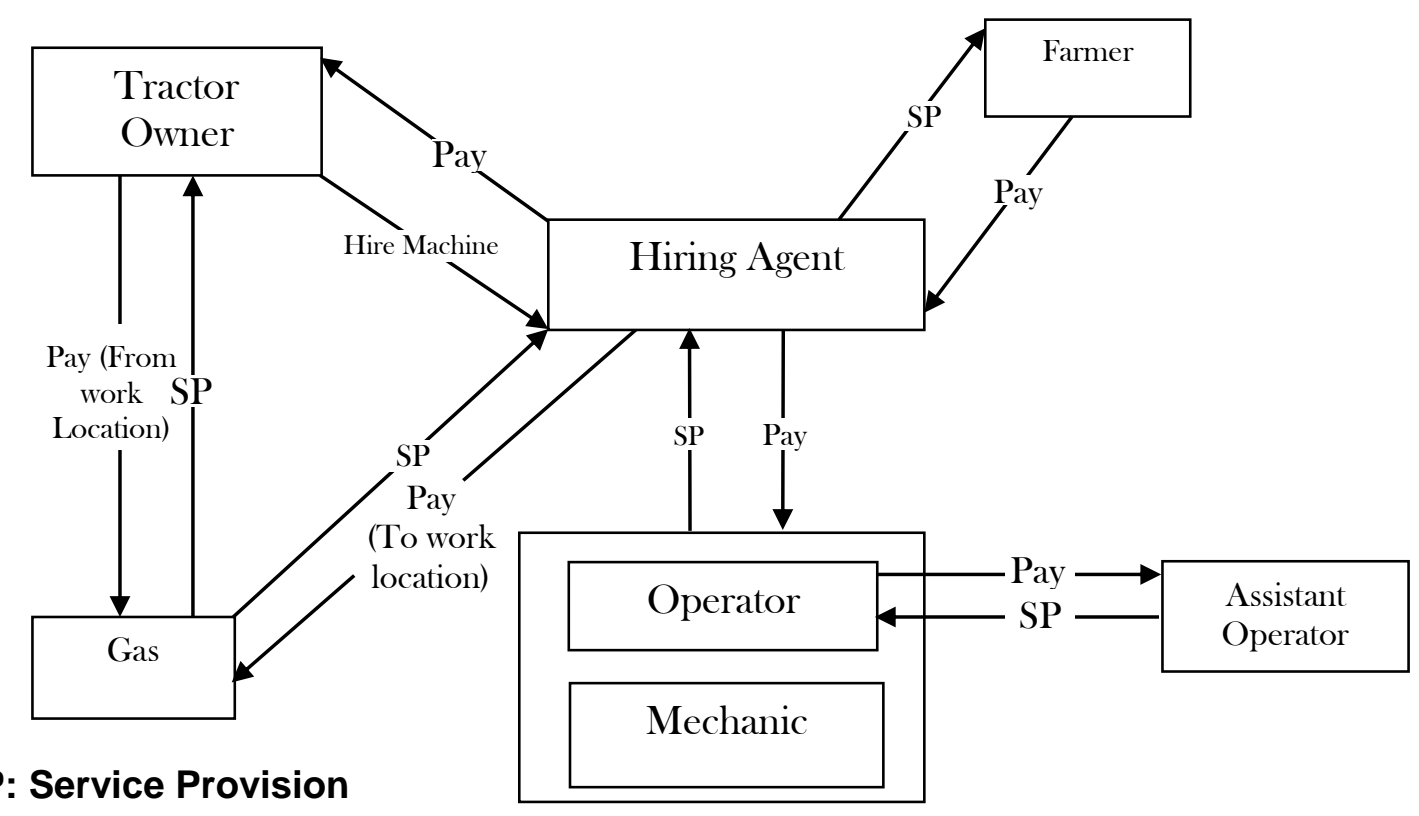

Figure 2: Model involving the Hiring Agent (Model I)

Booking agent mode (Model II): In this case, the booking agent finds farmers who need tractor-hiring services, and link such farmers with the tractor owner who provides the services and deducts an agreed $10 \%$ commission from the fee paid by farmers. He is a commission agent, who does not have the money to hire a tractor (Figure 3). The booking agent ensures that there is tractor-hiring job in his area for at least one week before contacting the tractor owner. He also ensures that farmers are satisfied with the services provided by the tractor owner. The booking agents only mobilize farmers who need tractor-hiring services, link them with the tractor owner, and receives commission for services rendered. 
Creative commons User License: CC BY-NC-ND

Abstracted by: EBSCOhost, Electronic Journals Service (EJS),

Google Scholar, Directory of Open Access Journals (DOAJ),

Journal Seek, Scientific Commons,

Food and Agricultural Organization (FAO), CABI and Scopus
Journal of Agricultural Extension

Vol. 21 (3) October, 2017

ISSN(e): 24086851; ISSN(Print); 1119944X

http://journal.aesonnigeria.org

http://www.ajol.info/index.php/jae

Email: editorinchief@aesonnigeria.org

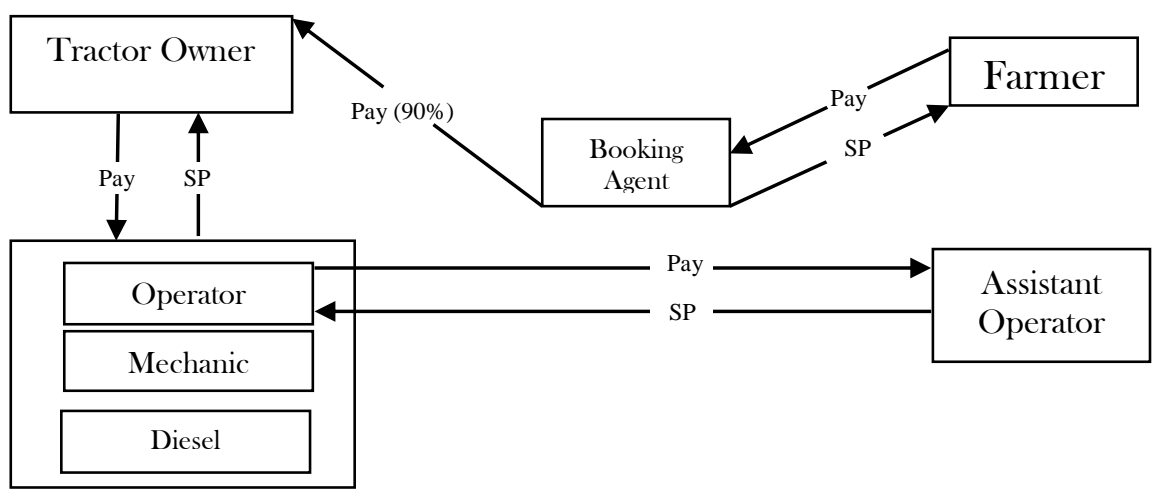

\section{SP: Service Provision}

\section{Figure 3: Model involving the booking agent (Model II)}

Direct owner-farmer transaction (Model III): Sometimes, the tractor owners get farmers who need tractor services directly. The author found the same model among non-TOHFAN interviewees. As depicted in Figure 4, the tractor owner bears the cost of diesel oil as well as pays the operator and mechanic.

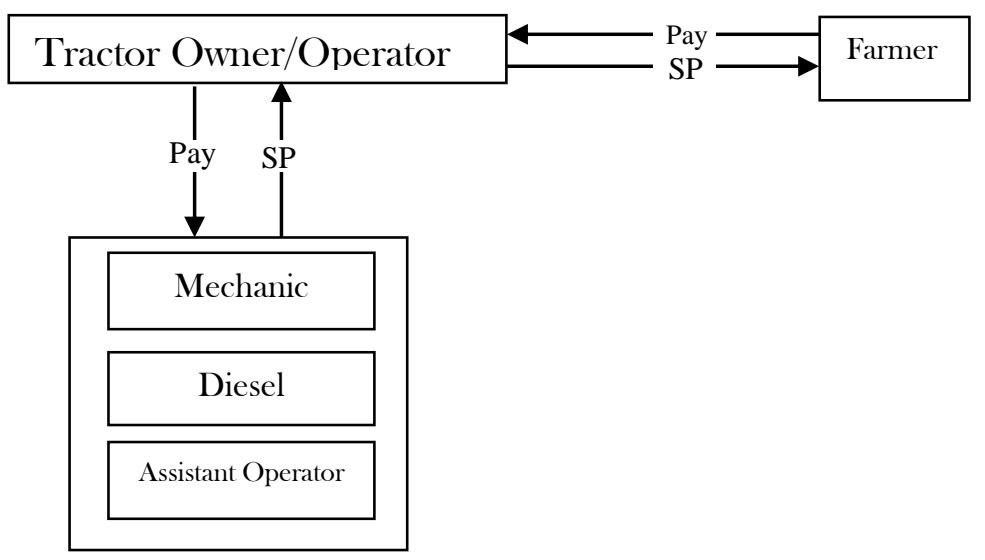

SP: Service Provision

Figure 4: Model involving no hiring/booking agent (Model III)

TOHFAN as booking agent (Model IV): In order to ensure continuous business operation, TOHFAN provides hiring services to big corporate farms by deploying tractor of members to work in such farms, thereby acting as booking agent (i.e. gets commission on each tractor working on such farm according to laid down rules) (Figure 5). 
Creative commons User License: CC BY-NC-ND

Abstracted by: EBSCOhost, Electronic Journals Service (EJS),

Google Scholar, Directory of Open Access Journals (DOAJ),

Journal Seek, Scientific Commons,

Food and Agricultural Organization (FAO), CABI and Scopus
Journal of Agricultural Extension

Vol. 21 (3) October, 2017

ISSN(e): 24086851; ISSN(Print); 1119944X

http://journal.aesonnigeria.org

http://www.ajol.info/index.php/jae

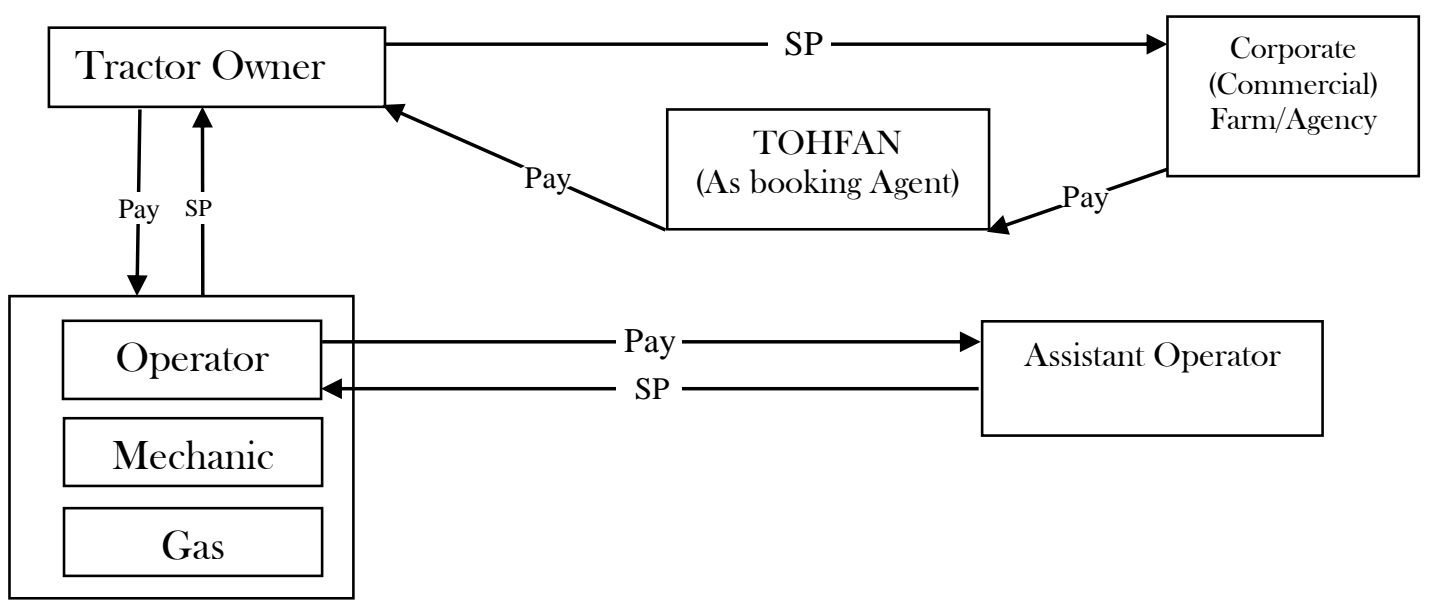

SP: Service Provision

Figure 5: Model involving TOHFAN as Booking Agent (Model IV)

\section{Major Characteristics of the Models with Respect to Direction of Payments among Partners}

Table 1 provides a summary of major characteristics of the models with respect to direction of payments among partners.

Table 1: Pay relationship among TOHFAN partners in the different operational models

\begin{tabular}{llllll}
\hline S/No & $\begin{array}{l}\text { Payments to } \\
\text { partners }\end{array}$ & Model I & Model II & Model III & Model IV \\
\hline 1 & $\begin{array}{l}\text { Payment of Tractor } \\
\text { Owner }\end{array}$ & Hiring Agent & $\begin{array}{l}\text { Booking } \\
\text { Agent }\end{array}$ & Owner/operator & TOHFAN \\
2 & $\begin{array}{l}\text { Payment to } \\
\text { mechanic }\end{array}$ & Hiring Agent & Owner & Owner/operator & Owner \\
3 & $\begin{array}{l}\text { Payment to } \\
\text { operator } \\
\text { Payment to } \\
\text { assistant operator }\end{array}$ & Hiring Agent & Owner & - & Owner \\
5 & $\begin{array}{l}\text { Payment for fuel } \\
\text { Hiring Agent }\end{array}$ & $\begin{array}{l}\text { Owner } \\
\text { H Owner }\end{array}$ & Owner/operator & Owner \\
6 & Farmer pays who? & Hiring Agent & $\begin{array}{l}\text { Booking } \\
\text { Agent }\end{array}$ & Owner/operator & TOHFAN \\
\hline
\end{tabular}

\section{Tractor Tracking System}

In order to prevent business downfall resulting from false declaration of working hours or hecterages worked by the operators, TOHFAN introduced the tractor tracking system. Through this system, the owner can: 
Creative commons User License: CC BY-NC-ND

Abstracted by: EBSCOhost, Electronic Journals Service (EJS),

Google Scholar, Directory of Open Access Journals (DOAJ),

Journal Seek, Scientific Commons,

Food and Agricultural Organization (FAO), CABI and Scopus
Journal of Agricultural Extension

Vol. 21 (3) October, 2017

ISSN(e): 24086851; ISSN(Print); $1119944 X$

http://journal.aesonnigeria.org

http://www.ajol.info/index.php/jae

Email: editorinchief@aesonnigeria.org

i. have timely access to tractor's location, idle time, parking time;

ii. monitor the time (working hours) when the tractor is due for servicing;

iii. detect if tractor is working on high gear (meaning that the operator is not doing his work properly and hence be called to take caution);

iv. assess the daily running trip showing of the tractor, and

v. get efficiency of work and customer satisfaction.

The tractor tracking device was installed by COTRAC Nigeria, at an initial cost $(\$ 55,000)$. The device is usually installed on the tractor at the distribution point during disbursement and allocation to owners. Owners or operators are not given the opportunity to know the exact location of the device on the tractor. Power-off alert is sent to owner in case of tampering with the device. Anytime the tractor is ignited/powered; the owner gets an e-mail alert. The annual subscription for the device is $\$ 18,900$ including maintenance cost. All TOHFAN tractors are tracked. Each tractor has a unique identification number which can be used to trace the working record for any particular day. The device stores the tractor work schedule for easy query on the computer. Figure 6 explains the relationship among players in the tracking system.

\section{TOHFAN TRACKING DEVICE Model}

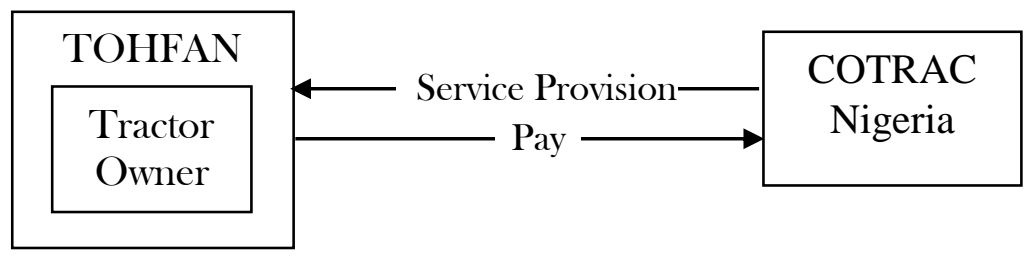

Figure 6: Model of TOHFAN tractor tracking system

The tractor tracking system benefits the tractor owner by reducing the problem of unfaithfulness on the part of operators. Unfaithfulness by the operators was estimated to reduce the number of working days from 18 to 14 per month, thereby reducing the income accruable to the owner. The 4 days lost due to unfaithfulness by the operator interprets to $\$ 80,000$ per month, and $\$ 720,000$ per year (of 9 months). This amount is about 10 times bigger than the sum of initial cost $(\$ 55,000)$ and annual subscription fee ( 18,900$)$ expended on the device. TOHFAN tractors last for 7 years, though some last for 10 years. From the second year, the owner pays an annual subscription fee in order to enjoy the benefits of the tracking device.

\section{Challenges faced by TOHFAN in tractor-hiring management}

This study identified two major challenges faced by TOHFAN in tractor-hiring management. They are:

1. High and unstable bank interest rate. This is largely due to unstable exchange rate of the Naira to other foreign currencies.

2. Banks do not understand (respect) idle months (and stops repayment within the period). Idle months for tractors are those periods when land preparation activities are not carried out by farmers. 
Creative commons User License: CC BY-NC-ND

Abstracted by: EBSCOhost, Electronic Journals Service (EJS),

Google Scholar, Directory of Open Access Journals (DOAJ),

Journal Seek, Scientific Commons,

Food and Agricultural Organization (FAO), CABI and Scopus
Journal of Agricultural Extension

Vol. 21 (3) October, 2017

ISSN(e): 24086851; ISSN(Print); 1119944X

http://journal.aesonnigeria.org

http://www.ajol.info/index.php/jae

Email: editorinchief@aesonnigeria.org

One of the measures adopted to mitigate the challenges was that tractor owners invest in supplementary business (off-farm activities) to offset the idle period. Such activities include milling / threshing / processing, transporting farm products, transporting nonfarm goods, local transportation, fetching water, firewood transport. Also, accelerated repayment (especially during the on-season) was encouraged in order to eliminate payment of high interest. Unavailability of spare parts, sharp practices by the operators and lack of proper records were identified as major constraints to efficient tractor-hiring management (Alabadan and Yusuf, 2013).

\section{Conclusion and Recommendations}

The findings of this study have revealed that the operational models employed by TOHFAN in tractor-hiring services are unique and effectively managed. Based on this conclusion, investors in tractor-hiring services should be encouraged (through creation of awareness by extension agencies) to emulate the TOHFAN example in tractor-hiring management. Models and operational strategies used by TOHAN (especially the tracking device) can be adapted by the public tractor-hiring services in order to ensure effective tractor-hiring management in Nigeria. Furthermore, agricultural extension efforts should be geared towards providing useful information to tractor-hiring service providers. Importantly, farmers should be encouraged to form cooperatives so as to attract incentives to procure needed agricultural machineries to generate income through hiring services.

\section{References}

Adamade, C. A. 1. and Jackson B. A. (2014). Agricultural mechanization: a strategy for food sufficiency. Scholarly Journal of Agricultural Science, 4(3): 152-156.

Akeju, O. M. (2015). Survey of agricultural mechanization in Nigeria, Synthesis of Interaction held at Sandrilia Hotel, Abuja, on $16^{\text {th }}$ November.

Alabadan, B. A. and Yusuf, Y. (2013). Tractor-hiring schemes in Nigeria: A case study of Federal Capital Territory (FCT). African Journal of Agricultural Research, 8(47): 5962-5966.

Bernier, L. and Hafsi, T, (2003). The changing nature of public entrepreneurship, Midwest Political Science Association Conference. USA.

Commission of the European Communities (2003) Green Paper: Entrepreneurship in Europe. Pp 45.

Dauda, S. M., Agidi, G. and Shotunde, M. A. (2010) Agricultural tractor ownership and off-season utilization in Ogun State, South Western Nigeria. African Journal of General Agriculture, 6(3): 95-103.

Federal Ministry of Agriculture \& Rural Development (FMARD) (2014). Private Sector Driven Agricultural Mechanization Framework (PSDAMF) and GES Application Strategy for ATA. (CD-ROM.) Nigeria.

Federal Ministry of Agriculture and Rural Development (FMARD) (2012). Rice transformation implementation plan, Agricultural Transformation Action Plan, Federal Ministry of Agriculture \& Rural Development.

Food and Agriculture Organization (FAO) (2011). Investment in agricultural mechanization in Africa: Conclusions and recommendations of a round table meeting of experts; Agricultural and Food Engineering Technical Report 8; 
Creative commons User License: CC BY-NC-ND

Abstracted by: EBSCOhost, Electronic Journals Service (EJS),

Google Scholar, Directory of Open Access Journals (DOAJ),

Journal Seek, Scientific Commons,

Food and Agricultural Organization (FAO), CABI and Scopus

\author{
Journal of Agricultural Extension \\ Vol. 21 (3) October, 2017 \\ ISSN(e): 24086851; ISSN(Print); 1119944X \\ http://journal.aesonnigeria.org \\ http://www.ajol.info/index.php/jae \\ Email: editorinchief@aesonnigeria.org
}

Ashburner, J.E., Kienzle, J., (Eds); Food and Agriculture Organization of the United Nations: Rome, Italy, 2011; p. 76.

Mijinyawa, Y. and Kisaiku, O. O. (2006). Assessment of the Edo State of Nigeria tractor hiring services. Agricultural Engineering International: the CIGR Ejournal. 8(10): Pp $1-14$.

NICA (2008). Tractor Hiring and Leasing. NICA Global Resources. http://www.nicanig.org. Assessed $4^{\text {th }}$ February, 2017.

Rowland, F. (2004). Hiring machinery rather than ownership. Agric.-Thriving Transit. pp. 134-138.

Sancho, F. (2010) Agricultural and rural entrepreneurship: concepts for modelling development. COMUNIICA. P 64-78.

Sims, B. and Kienzle, J. (2016). Making mechanization accessible to smallholder farmers in Sub-Saharan Africa. Environments, 3(11): 1-18. doi:10.3390/environments3020011 Assessed 7th July, 2017.

Takeshima, H., Edeh, H. Lawal, A. and Isiaka, M. (2014). Tractor owner-operators in Nigeria: Insights from a small survey in Kaduna and Nasarawa States. IFPRI Discussion Paper 01355, June, Pp 40.

Udoh, A. A. (2010). The place of entrepreneurship education in business education Programme. Journal of Business Educational Research and Development, 1(2): 110-116.

Umegbalu, I. C. E., Okonkwo, J. C., Ngini, J. O. and Chukwuma, E. C. (2013). Impact of Anambra state tractor and equipment hiring scheme on mechanization of rice production in Anambra state Nigeria: An appraisal. Journal of Applied Agricultural Research, 5(2): 61-71. 